Article

\title{
Pyrolyzed titanium dioxide/polyaniline as an efficient non-noble metal electrocatalyst for oxygen reduction reaction
}

\author{
Zhijuan Zou a, Hao Cheng a, Jingyu Wang a,b,*, Xijiang Han ${ }^{\mathrm{a}, \#}$ \\ a Department of Chemistry, Harbin Institute of Technology, Harbin 150001, Heilongjiang, China \\ ${ }^{\mathrm{b}}$ Key Laboratory for Large-Format Battery Materials and System (Ministry of Education), School of Chemistry and Chemical Engineering, Huazhong \\ University of Science and Technology, Wuhan 430074, Hubei, China
}

\section{A R T I C L E I N F O}

Article history:

Received 13 July 2014

Accepted 4 September 2014

Published 20 March 2015

Keywords:

Polyaniline

Titania

Pyrolyzation

Cathode catalyst

Oxygen reduction reaction

\begin{abstract}
A B S T R A C T
To overcome the prohibitive cost and poor durability of conventional Pt-based catalysts, $\mathrm{TiO}_{2} / \mathrm{C}$ was prepared by pyrolyzing a novel titanium dioxide/polyaniline $\left(\mathrm{TiO}_{2} / \mathrm{PANI}\right)$ composite. The prepared catalysts were characterized by scanning electron microscopy, transmission electron microscopy, Fourier transform infrared spectroscopy, Raman spectroscopy, X-ray photoelectron spectroscopy, $\mathrm{X}$-ray diffraction, cyclic voltammetry (CV), and linear sweep voltammetry. Interaction between $\mathrm{PANI}$ and $\mathrm{TiO}_{2}$ was found to inhibit the aggregation of $\mathrm{TiO}_{2}$ and its transformation from anatase to rutile. The catalytic activity of the $\mathrm{TiO}_{2} / \mathrm{C}$ first increased with increasing PANI content and then decreased; the optimum was achieved when the $\mathrm{PANI} / \mathrm{TiO}_{2}$ mass ratio was $35 / 100$. $\mathrm{CV}$ and $i-t$ curves showed that the prepared composite has a good catalytic stability.
\end{abstract}

(C) 2015, Dalian Institute of Chemical Physics, Chinese Academy of Sciences. Published by Elsevier B.V. All rights reserved.

$\mathrm{TiO}_{2}$ is often used as the base material for catalysts because of its good stability. Recently, $\mathrm{TiO}_{2}$ has also been examined as a fuel cell cathode catalyst because it can improve the stability [16] and methanol resistance of cathode catalysts and the selectivity and catalytic activity of 4-electron reactions $[17,18]$. Non-stoichiometric $\mathrm{TiO}_{2}$ has also been used as a base material for cathode catalysts [19].

Notably, $\mathrm{TiO}_{2}$ is an oxygen reduction catalyst. Zhang et al. [20] prepared a cathode catalyst via the hydrolysis of $\mathrm{TiCl}_{4}$ followed by heat treatment and used the resulting product in zinc-air batteries. Dam et al. [21] used $\mathrm{TiO}_{2}$ as a precursor to prepare a titanium carbonitride matrix after calcination at high temperature, and the resulting TiCNO product was a mixture of $\mathrm{TiO}_{2}$ and TiCN catalysts. The initial oxygen reduction potential and the carrying current of the titanium carbonitride catalyst

\footnotetext{
* Corresponding author. Tel: +86-451-86413702; Fax: +86-451-86418750; E-mail: jingyu.wang@163.com \# Corresponding author. Tel: +86-451-86413702; Fax: +86-451-86418750; E-mail: hanxijiang@hit.edu.cn This work was supported by the National Natural Science Foundation of China (21001037, 21071037, and 91122002), the Special Fund for Harbin Technological Innovation Talent (2013RFLXJ011), and the Research Fund for Talent Introduction of Huazhong University of Science and Technology (2014036). 
were significantly improved compared with those of pure $\mathrm{TiO}_{2}$. Additionally, Chisaka et al. [1] prepared a cathode catalyst, in which the main component was rutile $\mathrm{TiO}_{2}$, by heat treatment of TiCN. Their studies showed that the residual carbon did not integrate into the $\mathrm{TiO}_{2}$ lattice to form impurity defects. During heat treatment at elevated temperatures, $\mathrm{C}$ was instead incorporated into graphene, which then coated the surface of the $\mathrm{TiO}_{2}$; the coating played a role in the oxygen reduction electron transfer process. Although part of the $\mathrm{N}$ and Ti formed TiN, the $\mathrm{N}$ atoms did not influence the oxygen reduction activity because they were not integrated into the $\mathrm{TiO}_{2}$ lattice. Conversely, both oxygen defects generated in $\mathrm{TiO}_{2}$ during heat treatment at high temperatures and doped $\mathrm{N}$ are known to significantly affect the activity of $\mathrm{TiO}_{2}$ towards oxygen reduction. Recent studies have indicated that the (110) plane of $\mathrm{TiO}_{2}[1]$ is more conducive to the adsorption of oxygen. Thus, the (110) facets are favorable for oxygen reduction reactions. Despite the research results achieved to date, further investigations are required to adequately determine the mechanism of oxygen reduction over $\mathrm{TiO}_{2}$ and its performance as a catalyst or catalyst support.

$\mathrm{TiO}_{2}$ is a semiconductor, and as such its low conductivity limits its application in terms of oxygen reduction. Based on first-principle calculations, Zheng et al. [22] reported that for low-conductivity materials, the electron transfer efficiency is low, the reaction is limited to a small area on the material interface, and oxygen reduction tends to occur via a two-electron mechanism. The accumulation of the resulting products, $\mathrm{H}_{2} \mathrm{O}_{2}$ and $\mathrm{HO}_{2}-$ ions, is unfavorable for the reaction to continue. Conversely, the introduction of conductive carbon favors the reduction of oxygen via a four-electron mechanism, thereby improving the oxygen reduction performance of the material. These conclusions have been experimentally confirmed [22]. Chisaka et al. [1] studied $\mathrm{TiO}_{2}$ prepared via heat treatment of titanium carbonitride at high temperatures in $\mathrm{N}_{2}$ and $\mathrm{H}_{2}$ atmospheres. The resulting material exhibited oxygen reduction activity; $\mathrm{C}$ was not incorporated into the lattice of $\mathrm{TiO}_{2}$ but was instead present as a single layer of graphite on the surface of the $\mathrm{TiO}_{2}$. C played a primary role in electron transportation [23], and the oxygen defects formed during the heat treatment process had a decisive role in improving the performance of the oxygen reduction catalyst.

In this study, we first prepared a novel $\mathrm{TiO}_{2} /$ polyaniline (PANI) complex via a hydrothermal route, and a $\mathrm{TiO}_{2} / \mathrm{C}$ catalyst was obtained via subsequent pyrolysis. X-ray diffraction (XRD) and scanning electron microscopy (SEM) were used to study the crystal phase composition and morphology of the $\mathrm{TiO}_{2} / \mathrm{C}$, and its electrochemical performance was assessed. Moreover, the influence of the mass ratio of $\mathrm{PANI}$ to $\mathrm{TiO}_{2}$ and the pyrolysis temperature on the oxygen reduction performance of the catalyst was examined to establish optimum synthesis conditions to provide a reference for the future study of oxygen reduction $\mathrm{TiO}_{2}$ catalysts.

\section{Experimental}

\subsection{Catalyst preparation}

First, $2.282 \mathrm{~g}$ ammonium persulfate (APS, AR, Tianjin Damao Chemical Reagent Factory, Tianjin, China) was dissolved in $\mathrm{HCl}$ (36\%, AR, Beijing Chemical Plant, Beijing, China) solution $(0.1 \mathrm{~mol} / \mathrm{L})$ and held in an ice-water bath. Then, $0.3411 \mathrm{~g}$ of cetyltrimethylammonium chloride (CTAC, AR, Tianjin Guangfu Chemical Plant, Tianjin, China) dissolved in $\mathrm{HCl}$ solution $(0.1 \mathrm{~mol} / \mathrm{L})$ was added to a three-necked flask. After adding $0.92 \mathrm{~mL}$ aniline (AR, Sinopharm Chemical Reagent Co., Ltd., Shanghai, China), the mixture was mechanically stirred in an ice-water bath for $1 \mathrm{~h}$ to ensure uniform dispersion of the aniline monomers. The polymerization of the aniline monomers was initiated by the addition of the pre-cooled APS solution. The total volume of $\mathrm{HCl}$ solution $(0.1 \mathrm{~mol} / \mathrm{L})$ used was 100 $\mathrm{mL}$. The reaction solution was kept in an ice-water bath under mechanical stirring for $24 \mathrm{~h}$. After the reaction, the product was centrifuged and washed three times with industrial ethanol, distilled water, and absolute ethanol (AR, Sinopharm) in turn. Finally, the product was redispersed in $80 \mathrm{~mL}$ absolute ethanol before use. The $20 \mathrm{~mL}$ of polyaniline (PANI) ethanol dispersion was centrifuged and dried in a vacuum dryer at $60^{\circ} \mathrm{C}$ for $6 \mathrm{~h}$, and the concentration of the PANI nanofiber dispersion (11.46 $\mathrm{mg} / \mathrm{mL}$ ) was calculated by weighing the resulting solid powder. The yield of PANI was found to be about $97.6 \%$.

Next, $3 \mathrm{~mL}$ of tetrabutyl titanate (AR, Sinopharm) was mixed with a certain amount of ethanol. After ultrasonic dispersion, the PANI ethanol dispersion was added, and the mixture was ultrasonically dispersed for another $10 \mathrm{~min}$. The total volume of the ethanol dispersion was set at $30 \mathrm{~mL}$. Then, under magnetic stirring, $10 \mathrm{~mL}$ of distilled water was added dropwise to the above mixture. The mixture was stirred at $70{ }^{\circ} \mathrm{C}$ for a further 30 min to ensure complete hydrolysis. The resulting precipitate was centrifuged, washed three times with distilled water, and then dispersed into $60 \mathrm{~mL}$ of aqueous $\mathrm{HCl}$ solution $(1$ $\mathrm{mol} / \mathrm{L}$ ). The mixture was transferred to a $250 \mathrm{~mL}$ three-necked flask and mechanically stirred at $70{ }^{\circ} \mathrm{C}$ for $4 \mathrm{~h}$. The resulting solution was then transferred to a $35 \mathrm{~mL}$ autoclave and hydrothermally treated at $150{ }^{\circ} \mathrm{C}$ for $18 \mathrm{~h}$. The precipitated powder was centrifuged, washed three times each with industrial ethanol and distilled water, and dried at $60^{\circ} \mathrm{C}$. Finally, the obtained solid was ground and calcined in a tube furnace at 800 ${ }^{\circ} \mathrm{C}$ under flowing $\mathrm{N}_{2}$ to generate the $\mathrm{TiO}_{2} / \mathrm{C}$ catalyst.

\subsection{Catalyst characterization}

XRD measurements were performed with a Rigaku D/Max-RB X-ray diffractometer (Japan) using $\mathrm{Cu} K_{\alpha}$ radiation at a tube voltage of $40 \mathrm{kV}$ and operating current of $30 \mathrm{~mA}$. The morphologies of the samples were analyzed with a field emission scanning electron microscope (FE-SEM; Philips FEI-Sirion 200) and a transmission electron microscope (TEM; FEI TECNAI G2). Raman spectra were collected with a Renishaw inVia Rama spectrometer using a He-Ne laser $(0.1 \mathrm{~mW})$ at 633 $\mathrm{nm}$. Fourier transform infrared spectra (FT-IR) were collected using a Nicolet Avatar 360 spectrometer (USA). X-ray photoelectron spectroscopy (XPS) measurements were performed with a ULVAC PHI5700ESCA spectrometer. Thermal analysis of the samples was carried out using an SDT Q600 thermogravi- 
metric-differential scanning thermal analyzer (TGA-DSC; USA).

\subsection{Catalyst performance}

The Ti/C catalyst ( $4 \mathrm{mg}$ ) was placed in a $1.5 \mathrm{~mL}$ centrifuge tube, and $0.4 \mathrm{~mL}$ of absolute ethanol, $0.4 \mathrm{~mL}$ of distilled water, and $20 \mu \mathrm{L}$ of $0.5 \mathrm{wt} \%$ Nafion solution (5\% Nafion in isopropyl alcohol, analytically pure, Alfa Aesar Tianjin Chemical Co., China) were then added. Catalyst was dispersed in the mixture by ultrasonication. To obtain the working electrode, $4 \mu \mathrm{L}$ of the catalyst dispersion was dripped and uniformly spread onto the surface of a glassy carbon rotating disk electrode (RDE; diameter $4 \mathrm{~mm}$ ), and naturally dried. After each test, the electrode was successively washed with distilled water and absolute ethanol and then dried in air.

The electrochemical properties of the catalyst were measured with a three-electrode system in KOH (AR, Tianjin Sailboat Chemical Reagent Co., Ltd., Tianjin, China) electrolyte $(0.1$ mol/L) at room temperature using a Shanghai Chen Hua CHI650D electrochemical workstation. The working electrode was the catalyst-loaded glassy carbon RDE, the counter electrode was a platinum wire, and the reference electrode was an $\mathrm{Ag} / \mathrm{AgCl}$ electrode. To ensure gas saturation, $30 \mathrm{~min}$ of aeration was carried out before each test. The scan range was 0.2 to -0.8 $\mathrm{V}$, and the scan speed was $5 \mathrm{mV} / \mathrm{s}$.

\section{Results and discussion}

\subsection{Influence of the mass ratio of PANI to $\mathrm{TiO}_{2}$ on the performance of the $\mathrm{TiO}_{2} / \mathrm{C}$ composites}

TEM images of the synthesized PANI before and after its combination with $\mathrm{TiO}_{2}$ are shown in Fig. 1. The $\mathrm{HCl}$ doped PANI had a fiber-like structure with rough spiculations on its surface, as shown in Fig. 1(b). Fig. 1(a) shows that the $\mathrm{TiO}_{2}$ nanoparticles were closely and uniformly adhered to the surface of the PANI nanofibers.

The effect of the PANI on the phase composition of the $\mathrm{TiO}_{2}$ was investigated by XRD. The presence of PANI in the composites was found to change the phase composition and crystal size of the $\mathrm{TiO}_{2}$. Fig. 2 shows the XRD patterns of $\mathrm{TiO}_{2} / \mathrm{PANI}$ composites with different PANI contents (the amount of $\mathrm{TiO}_{2}$ was calculated according to the theoretical yield). The proportion of anatase $\mathrm{TiO}_{2}$ in the composites increased, and the pro-
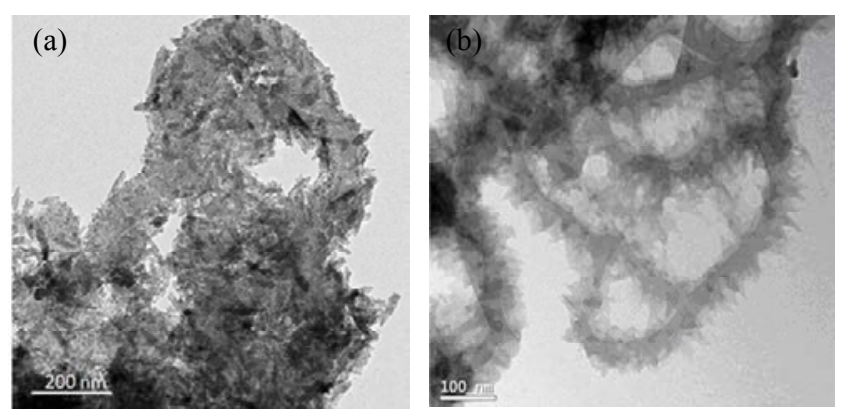

Fig. 1. TEM images of (a) PANI nanofibers and (b) $\mathrm{TiO}_{2} / \mathrm{PANI}$ with $\mathrm{PANI} / \mathrm{TiO}_{2}=40 / 100$.

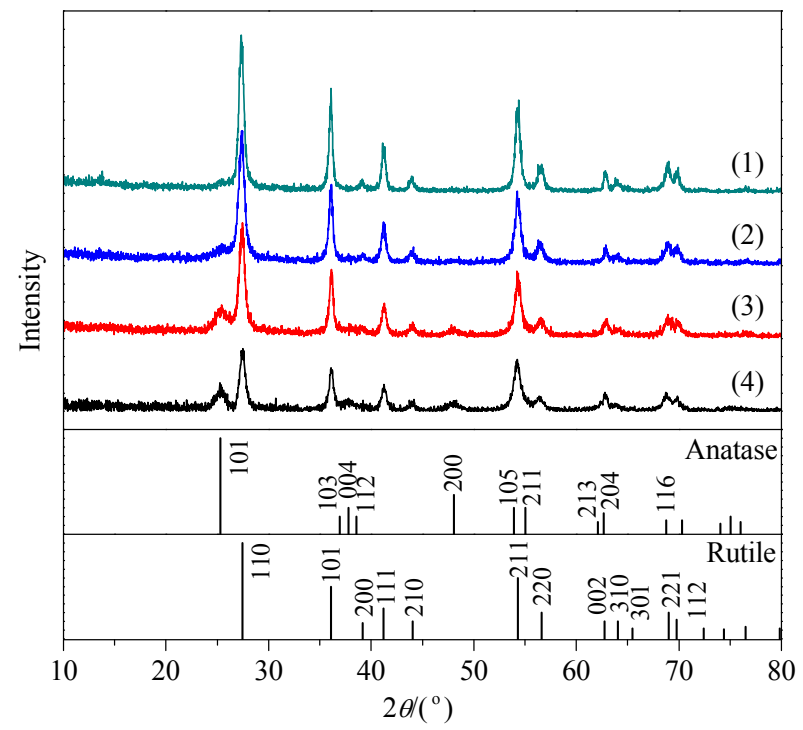

Fig. 2. XRD patterns of $\mathrm{TiO}_{2} / \mathrm{PANI}$ composites with different PANI contents. $\mathrm{PANI} / \mathrm{TiO}_{2}$ mass ratio: (1) 5/100; (2) 20/100; (3) 30/100; (4) $40 / 100$.

portion of rutile $\mathrm{TiO}_{2}$ decreased with increasing PANI content. The rutile phase was the dominant phase in all of the obtained composites. When the mass ratio of PANI to $\mathrm{TiO}_{2}$ was $5 / 100$, the product was pure rutile- $\mathrm{TiO}_{2}$. At $\mathrm{PANI} / \mathrm{TiO}_{2}=40 / 100$, the proportion of rutile $\mathrm{TiO}_{2}$ decreased to $74.6 \%$ while that of anatase $\mathrm{TiO}_{2}$ increased to $25.4 \%$. It is well-known that rutile- $\mathrm{TiO}_{2}$ is the thermodynamically stable state. Under the hydrothermal synthesis conditions and high concentrations of hydrochloride employed, $\mathrm{TiO}_{2}$ is expected to completely transform into rutile.

However, the interaction between $\mathrm{TiO}_{2}$ and the surface of the introduced one-dimensional PANI fibers inhibited the anatase-to-rutile transformation, consequently leading to the formation of anatase $\mathrm{TiO}_{2}$ in the composite [24]. Moreover, previous studies have shown that the crystal transformation from anatase to rutile occurs at the interfaces of the anatase particles, suggesting that weakened agglomeration of anatase will inhibit the formation of rutile $\mathrm{TiO}_{2}$. As observed in Fig. 2, the intensity of the characteristic XRD peaks of $\mathrm{TiO}_{2}$ decreased, leading to peak broadening, with increasing PANI content. These results confirm that higher PANI content increased the attachment of $\mathrm{TiO}_{2}$ on the surface of the PANI fibers and inhibited the agglomeration and formation of large $\mathrm{TiO}_{2}$ particles. To support the above analysis, Scherrer's formula was used to calculate the particle size of $\mathrm{TiO}_{2}$ in the composites, and the results are given in Table 1.

\section{Table 1}

Phase composition and crystallite size of $\mathrm{TiO}_{2} / \mathrm{PANI}$ with varied PANI contents.

\begin{tabular}{|c|c|c|c|c|}
\hline \multirow{2}{*}{$\begin{array}{l}\mathrm{PANI} / \mathrm{TiO}_{2} \\
\text { mass ratio }\end{array}$} & \multicolumn{2}{|c|}{ Mass fraction (\%) } & \multicolumn{2}{|c|}{ Diameter (nm) } \\
\hline & Anatase- $\mathrm{TiO}_{2}$ & Rutile- $\mathrm{TiO}_{2}$ & $\begin{array}{c}\text { Anatase- } \mathrm{TiO}_{2} \\
(101)\end{array}$ & $\begin{array}{c}\text { Rutile- } \mathrm{TiO}_{2} \\
(110)\end{array}$ \\
\hline $5 / 100$ & 0 & 100 & - & 15.31 \\
\hline $20 / 100$ & 7.8 & 92.2 & 8.36 & 12.58 \\
\hline $30 / 100$ & 14.4 & 85.6 & 6.82 & 12.13 \\
\hline $40 / 100$ & 25.4 & 74.6 & 6.82 & 12.02 \\
\hline
\end{tabular}


The interaction between PANI and $\mathrm{TiO}_{2}$ was further investigated by FT-IR spectroscopy. The FT-IR spectra of the $\mathrm{TiO}_{2} /$ PANI composites are shown in Fig. 3. The peaks at 3502, 1573 , and $1490 \mathrm{~cm}^{-1}$ were indexed to the stretching vibration absorptions of $\mathrm{N}-\mathrm{H}$ single bonds, $\mathrm{C}=\mathrm{N}$ double bonds, and $\mathrm{C}=\mathrm{C}$ double bonds, respectively. The peaks at 1305 and $1248 \mathrm{~cm}^{-1}$ were assigned to the $\mathrm{C}-\mathrm{N}$ stretching vibration absorption of benzene rings. The peaks at 1143 and $802 \mathrm{~cm}^{-1}$ arise from the IR absorption of quinone and benzene rings in the doped PANI, respectively. The absorption from 400 to $1000 \mathrm{~cm}^{-1}$ corresponded to the network structure of $\mathrm{O}-\mathrm{Ti}-\mathrm{O}$ in the $\mathrm{TiO}_{2}$ component. Furthermore, differences in absorption at and below $802 \mathrm{~cm}^{-1}$ could be distinguished among the spectra. At high $\mathrm{TiO}_{2}$ contents in the composite, the absorption peak corresponding to $\mathrm{TiO}_{2}$ overlapped with that corresponding to PANI absorption at lower wavenumber owing to the existence of the interaction between them. The gradual disappearance of the absorption peak at $802 \mathrm{~cm}^{-1}$, shift in the 0-Ti-0 absorption peak, and reduction in the intensity of the remaining PANI absorption peaks confirm the existence of interactions between PANI and $\mathrm{TiO}_{2}$. We speculate that the $\mathrm{N}-\mathrm{H}$ groups of PANI interacted with the surface hydroxy groups of $\mathrm{TiO}_{2}$ at the interfaces [24].

The $\mathrm{TiO}_{2} / \mathrm{PANI}$ composite with $\mathrm{PANI} / \mathrm{TiO}_{2}=40 / 100$ was characterized by XPS to analyze the chemical bonds present and their associated energy to further confirm the interaction between $\mathrm{TiO}_{2}$ and PANI. Fig. 4(a) shows the resulting XPS spectrum of the $\mathrm{TiO}_{2} / \mathrm{PANI}$ composite. The XPS spectrum confirmed the presence of $\mathrm{C}, \mathrm{O}, \mathrm{Ti}$, and $\mathrm{N}$ in the composite. The peaks at binding energy of 284.3, 530.1, 458.8, and $400.1 \mathrm{eV}$ could be well indexed to $\mathrm{C} 1 s, 01 s$, Ti $2 p$, and $\mathrm{N} 1 s$, respectively. The fractions of the elements were calculated to be C $49.95 \%, 0$

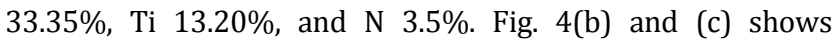
high-resolution XPS spectra for C $1 s$ and $01 s$, respectively. The C $1 s$ XPS spectrum displayed three peaks at 284.6, 286.4, and $288.5 \mathrm{eV}$ following Gaussian fitting, where the carbon atoms with binding energy of $288.5 \mathrm{eV}$ are associated with $\mathrm{C}-\mathrm{O}-\mathrm{Ti}$ bonds in the composite. The $01 \mathrm{~s}$ peak could be divided into two peaks at 530.0 and $531.9 \mathrm{eV}$ after deconvolution. The peak at $530.0 \mathrm{eV}$ is associated with Ti-O bonds, whereas the peak at $531.9 \mathrm{eV}$ confirmed a change in the Ti-O bond environment in

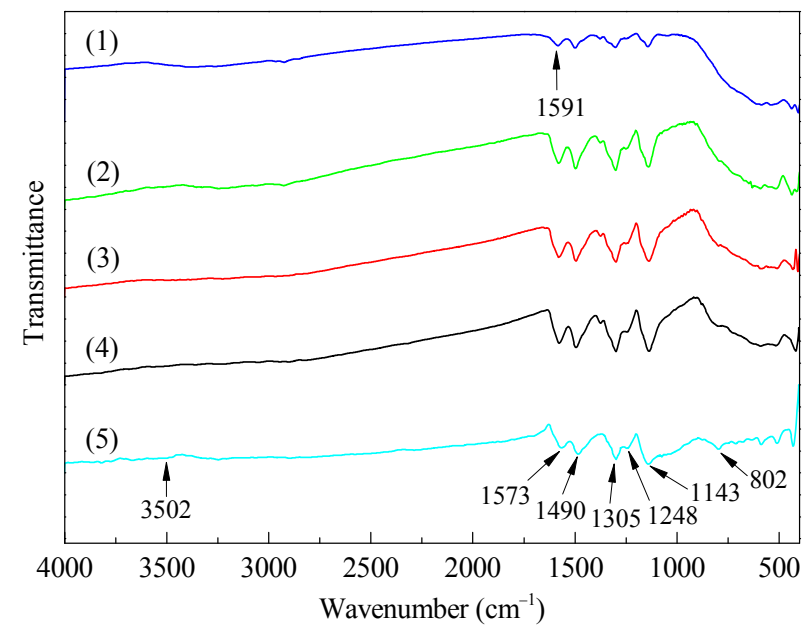

Fig. 3. FT-IR spectra of $\mathrm{TiO}_{2} / \mathrm{PANI}$ composites with different PANI contents. PANI/TiO 2 : (1) 5/100; (2) 10/100; (3) 20/100; (4) 30/100; (5) $40 / 100$.

the $\mathrm{TiO}_{2}$. Based on the XRD patterns and FT-IR spectra, we believe that PANI formed hydrogen bond-like interactions with hydroxyl groups on the surface of the $\mathrm{TiO}_{2}$ via amino or imino groups during the synthesis of the composite materials [24].

Linear sweep voltammetry (LSV) curves were recorded to analyze the catalytic activity of the $\mathrm{TiO}_{2} / \mathrm{C}$ composites for the oxygen reduction reaction before and after pyrolysis of $\mathrm{TiO}_{2} /$ PANI. The LSV curves obtained before and after pyrolysis are shown in Fig. 5. The performance of the $\mathrm{TiO}_{2} / \mathrm{C}$ catalyst towards oxygen reduction improved with increasing PANI content, reaching a maximum at a $\mathrm{PANI} / \mathrm{TiO}_{2}=30 / 100-$ 40/100. This can be ascribed to the extension of the limited conductivity of $\mathrm{TiO}_{2}$ that enhanced the activity of the catalyst towards oxygen reduction. Moreover, the $\mathrm{N}$ in the framework of PANI may also have acted as an active center for the oxygen reduction reaction $[25,26]$. As the PANI content increased, the content of $\mathrm{C}-\mathrm{N}$ derived from the pyrolyzation also increased, resulting in a higher catalytic rate of oxygen reduction $[25,26]$. As noted, further increases in PANI did not lead to further improvement in catalytic activity, indicating the existence of a limitation in the interaction at the interface between PANI and

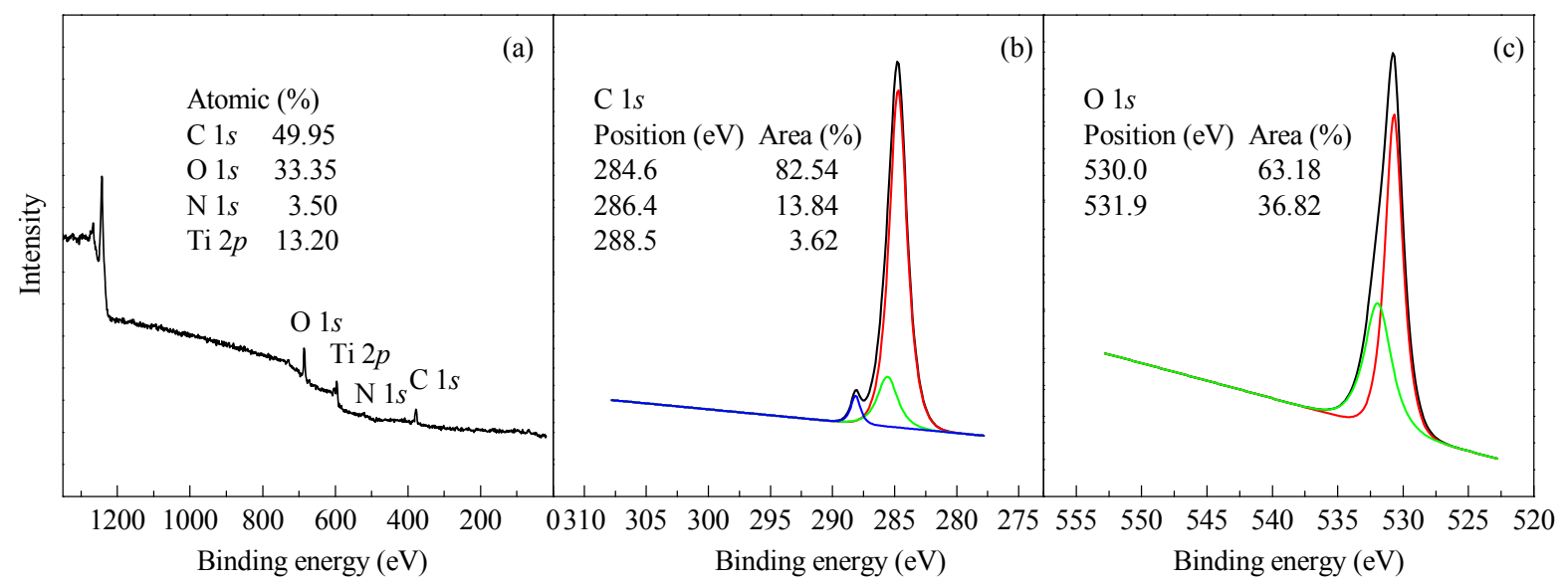

Fig. 4. (a) XPS spectrum of $\mathrm{TiO}_{2} / \mathrm{PANI}$ with $\mathrm{PANI} / \mathrm{TiO}_{2}=40 / 100$; (b) High-resolution XPS spectra of $\mathrm{C} 1 \mathrm{~s}$; (c) High-resolution XPS spectra of $\mathrm{O} 1 s$. 


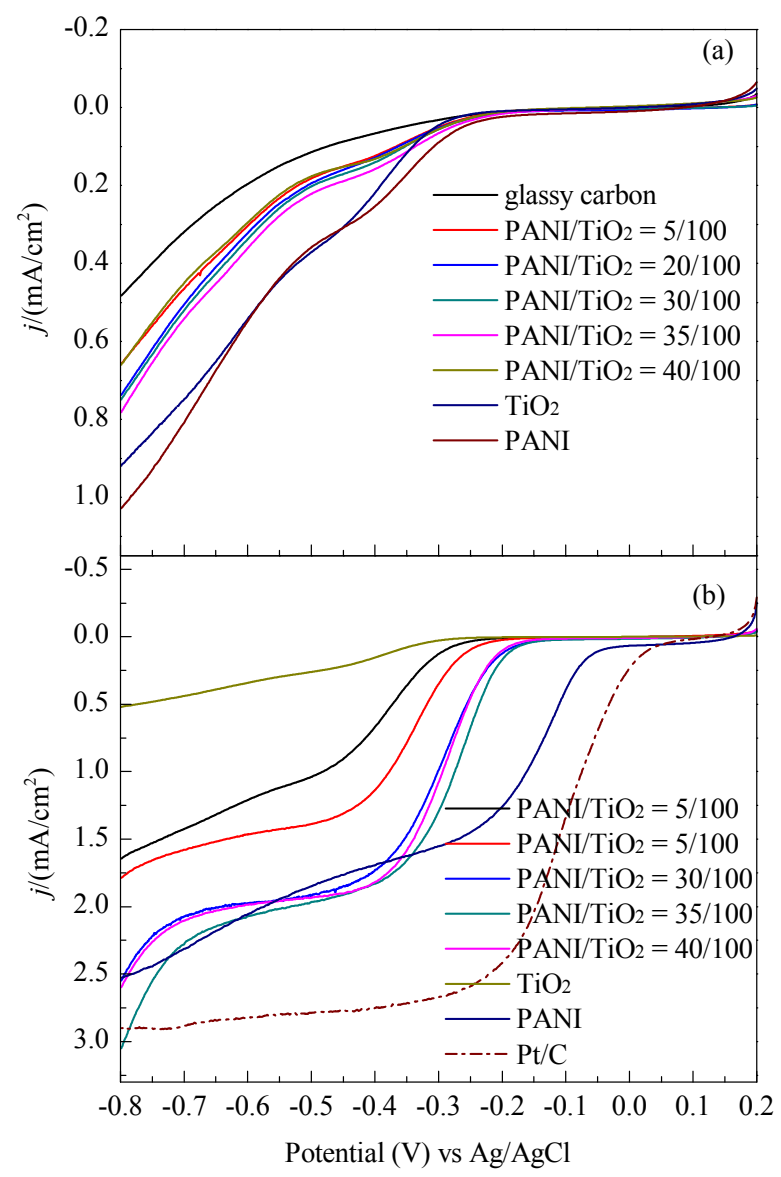

Fig. 5. $\mathrm{LSV}$ plots for $\mathrm{TiO}_{2} / \mathrm{C}$ derived from $\mathrm{TiO}_{2} / \mathrm{PANI}$ composites with different PANI contents before (a) and after (b) pyrolyzation at $800{ }^{\circ} \mathrm{C}$ for $1 \mathrm{~h}$ in $\mathrm{N}_{2}$. Electrolyte: $\mathrm{O}_{2}$ saturated $\mathrm{KOH}(0.1 \mathrm{~mol} / \mathrm{L})$; scanning rate: 5 $\mathrm{mV} / \mathrm{s}$; rotation speed: $900 \mathrm{r} / \mathrm{min}$.

$\mathrm{TiO}_{2}$ at which $\mathrm{TiO}_{2}$ cannot act as a good cocatalyst. This limitation may have arose from the limited catalytic activity of the $\mathrm{N}$-doped $\mathrm{C}$ generated from the pyrolysis of pure PANI, which was lower than that of commercial $\mathrm{Pt} / \mathrm{C}$ materials. The LSV curve of $\mathrm{Pt} / \mathrm{C}$ has a wide current plateau and strong limiting diffusion current density, indicating a diffusion-controlled process related to an efficient $4 \mathrm{e}^{-}$dominated oxygen reduction pathway. Conversely, current stabilization could not be attained in the $\mathrm{N}$-doped $\mathrm{C}$ material obtained from pyrolysis of pure PANI. This suggests a likelihood of a transformation process involving $2 \mathrm{e}^{-}$, namely the transformation of $\mathrm{O}_{2}$ into $\mathrm{OOH}^{-}$ [22]. This represents a huge step behind the study of $\mathrm{N}$-doped $\mathrm{C}$ materials obtained from the pyrolysis of GO-PANI [26]. The LSV curve of the $\mathrm{TiO}_{2} / \mathrm{C}$ composite material from pyrolyzed $\mathrm{TiO}_{2} /$ PANI displayed an obvious current plateau, after which the diffusion current density increased continuously, which can be ascribed to the effects of combined $2 \mathrm{e}^{-}$and $4 \mathrm{e}^{-}$pathways.

Although the influence of metal oxides on the enhancement of catalytic activity of $\mathrm{C}$ materials is not considerable, the number of studies on fuel cells involving metal oxides has gradually increased in the last several years owing to the cost-effective use of metal oxides, and more importantly, their dramatic electrochemical stabilization of catalysts and enhancement of the working lifetime of fuel cells [27]. The $i-t$ curves of the pure

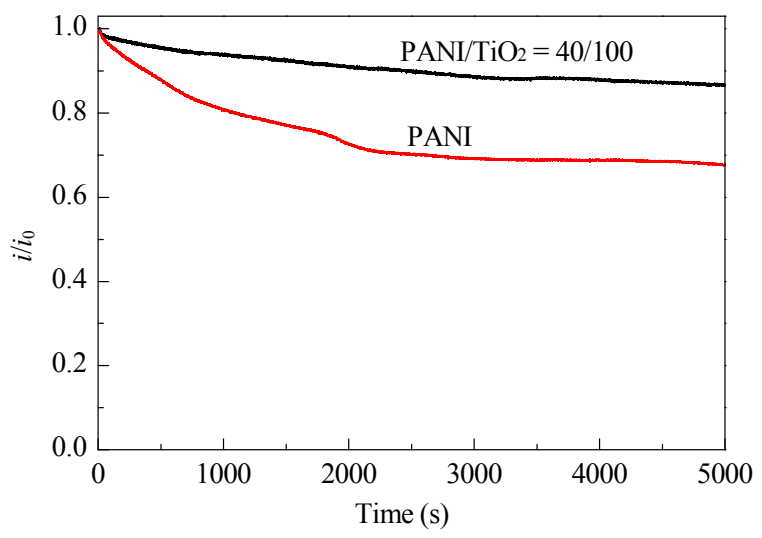

Fig. 6. $i-t$ plots of $\mathrm{TiO}_{2} / \mathrm{C}$ and $\mathrm{C}$ derived from pyrolyzation of $\mathrm{TiO}_{2} / \mathrm{PANI}$ composite and PANI, respectively, at $800^{\circ} \mathrm{C}$ for $1 \mathrm{~h}$ in $\mathrm{N}_{2}$. Electrolyte: $\mathrm{O}_{2}$ saturated $\mathrm{KOH}(0.1 \mathrm{~mol} / \mathrm{L})$; initial potential: $-0.5 \mathrm{~V}$; rotation speed: 900 $\mathrm{r} / \mathrm{min}$.

carbonized PANI and composite prepared at a $\mathrm{PANI} / \mathrm{TiO}_{2}=$ 40/100 were measured and are shown in Fig. 6. Under similar conditions, the current loss of the composite was only $13 \%$ after 5000 s reaction, while the current loss for the N-doped C material obtained from the carbonization of pure PANI reached as high as $32 \%$. Namely, although the product of the carbonization of pure PANI exhibited slightly better catalytic activity than the product from $\mathrm{TiO}_{2} / \mathrm{PANI}$, the stability of the latter was much more superior to that of the former. Further, CV was performed to study the cycle stability of the $\mathrm{TiO}_{2} / \mathrm{C}$ catalyst. Fig. 7 shows no apparent fluctuation in the electrochemical response of $\mathrm{TiO}_{2} / \mathrm{C}$ after 100 cycles, which is consistent with the results of the above $i-t$ curves. As deduced, the introduction of $\mathrm{TiO}_{2}$ and the carbonization of the conductive polymer reduced the carbon content in the catalyst and improved the cyclic sta-

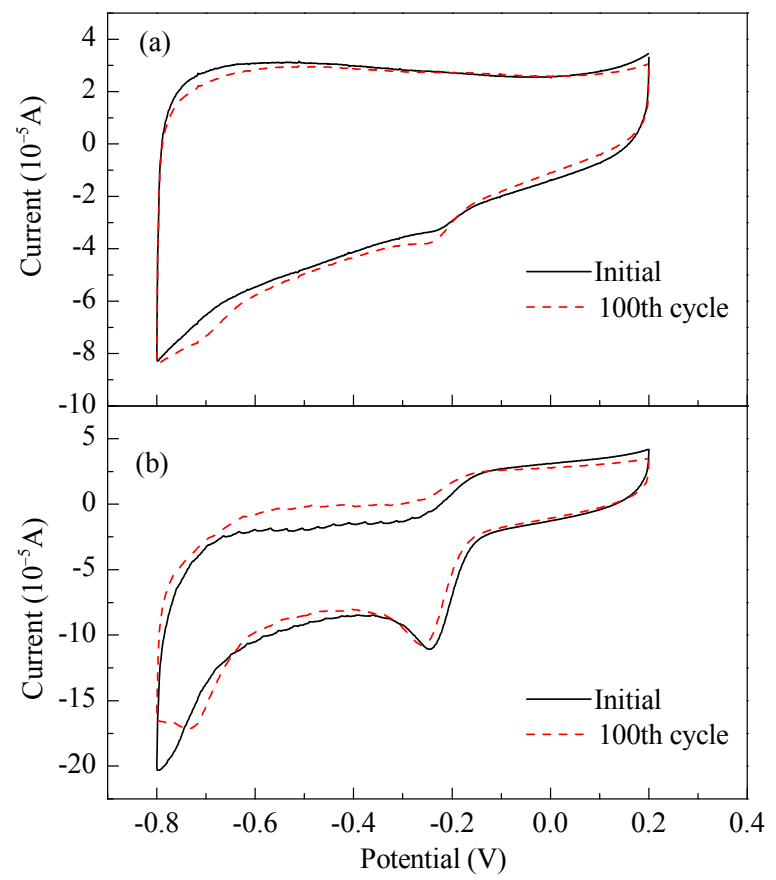

Fig. 7. CV plots in (a) $\mathrm{N}_{2}$ and (b) $\mathrm{O}_{2}$ of $\mathrm{TiO}_{2} / \mathrm{C}$ derived from pyrolyzation of $\mathrm{TiO}_{2} / \mathrm{PANI}$ composite at $800{ }^{\circ} \mathrm{C}$ for $1 \mathrm{~h}$ in $\mathrm{N}_{2}$. 
bility of the carbon material as an electrocatalyst or catalyst support.

Additionally, the TG curve of the pre-carbonized composite with $\mathrm{PANI} / \mathrm{TiO}_{2}=40 / 100$ was recorded in air to investigate the real mass ratio of PANI to $\mathrm{TiO}_{2}$ (Fig. 8). The final mass loss reached $34.8 \%$ after heating to $950{ }^{\circ} \mathrm{C}$. The mass loss of $4.0 \%$ in the range from 0 to $100{ }^{\circ} \mathrm{C}$ can be attributed to the evaporation of absorbed water; the other $30.8 \%$ loss can be ascribed to the combustion of PANI in the composite.

\subsection{Influence of pyrolysis on the oxygen reduction performance of $\mathrm{TiO}_{2} / \mathrm{C}$ composites}

Fig. 9 displays a TEM image of $\mathrm{TiO}_{2} / \mathrm{C}$ derived from the pyrolysis of the $\mathrm{TiO}_{2} / \mathrm{PANI}$ composite with $\mathrm{PANI} / \mathrm{TiO}_{2}=40 / 100$ at $800{ }^{\circ} \mathrm{C}$ for $1 \mathrm{~h}$ in $\mathrm{N}_{2}$. Compared with the resaits in Figs. 1(a) and 3 , the fiber-like structure disappeared, and the $\mathrm{TiO}_{2}$ was coated by carbon material with no obvious morphology. Thus, the pyrolysis converted the PANI into an amorphous carbon material.

FT-IR spectra of the $\mathrm{TiO}_{2} / \mathrm{PANI}$ composites with $\mathrm{PANI} / \mathrm{TiO}_{2}$ $=40 / 100$ before and after pyrolysis are shown in Fig. 10. The composite obtained following pyrolysis displayed peaks at $3416 \mathrm{~cm}^{-1}$, assigned to the stretching vibration of $\mathrm{N}-\mathrm{H}$ bonds in PANI; $1575 \mathrm{~cm}^{-1}$, ascribed to the stretching vibration of $\mathrm{C}=\mathrm{N}$ in

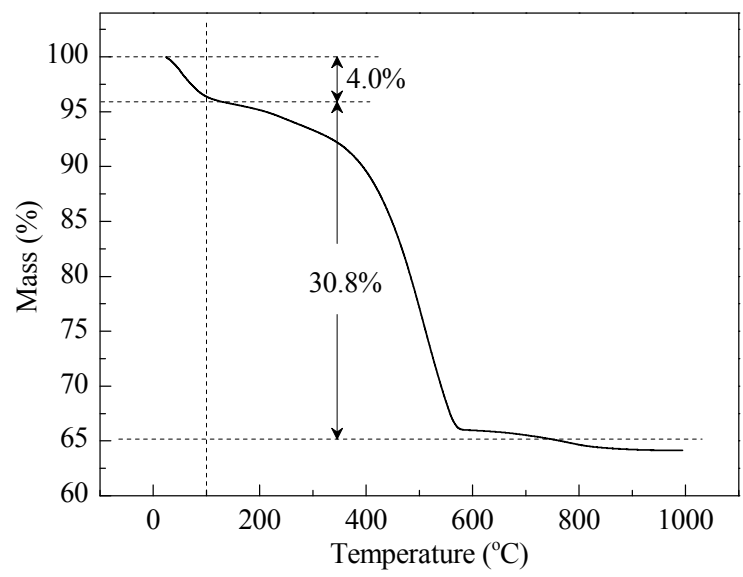

Fig. 8. TGA curve of $\mathrm{TiO}_{2} / \mathrm{PANI}$ with $\mathrm{PANI} / \mathrm{TiO}_{2}=40 / 100$.

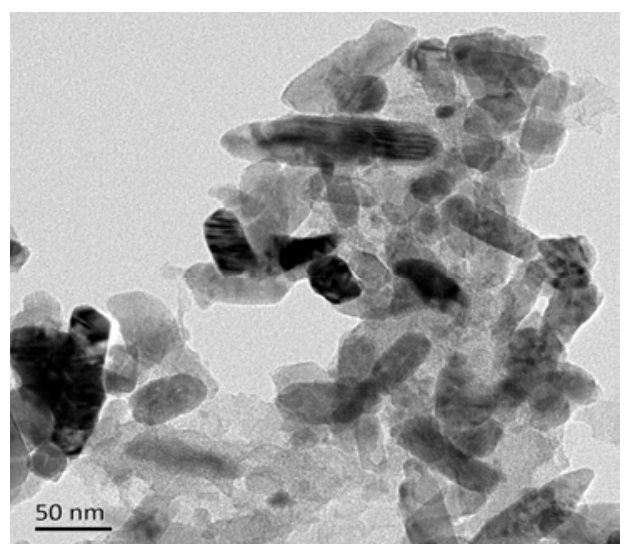

Fig. 9. TEM image of $\mathrm{TiO}_{2} / \mathrm{C}$ derived from pyrolyzation of $\mathrm{TiO}_{2} / \mathrm{PANI}$ composite with $\mathrm{PANI} / \mathrm{TiO}_{2}=40 / 100$ at $800{ }^{\circ} \mathrm{C}$ for $1 \mathrm{~h}$ in $\mathrm{N}_{2}$.

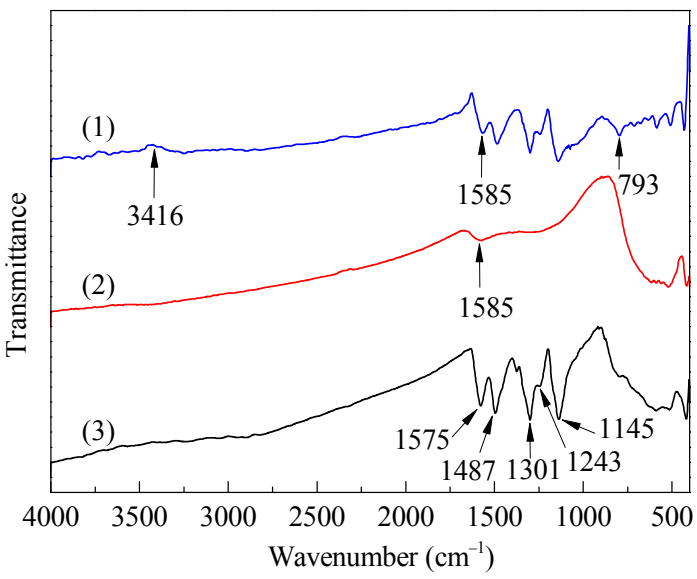

Fig. 10. FT-IR spectra of (1) $\mathrm{TiO}_{2} / \mathrm{PANI},(2) \mathrm{TiO}_{2} / \mathrm{C}\left(800{ }^{\circ} \mathrm{C}\right.$ for $1 \mathrm{~h}$ in $\mathrm{N}_{2}$ ), and (3) PANI.

the quinone ring; $1487 \mathrm{~cm}^{-1}$, attributed to the stretching vibration of $\mathrm{C}=\mathrm{C}$ bonds in the benzene ring; and 1301 and $1243 \mathrm{~cm}^{-1}$, ascribed to the stretching vibration of $\mathrm{C}-\mathrm{N}$ bonds. The absorption peak at $1145 \mathrm{~cm}^{-1}$ was indexed to the quinone ring doped into PANI, and no assignable absorption peaks were observed below $793 \mathrm{~cm}^{-1}$. The samples maintained their infrared absorption in the range of $400-1000 \mathrm{~cm}^{-1}$ before and after pyrolysis, indicating that the network structure of $\mathrm{O}-\mathrm{Ti}-\mathrm{O}$ did not apparently change after carbonization. The small absorption peak at $1585 \mathrm{~cm}^{-1}$ originated from the absorption of water on the surface of the $\mathrm{TiO}_{2}$. Therefore, the original structure of PANI was damaged during pyrolysis, but the structure of $\mathrm{O}-\mathrm{Ti}-\mathrm{O}$ network was unchanged.

Fig. 11 shows the Raman spectra of the $\mathrm{TiO}_{2} / \mathrm{PANI}$ composite with a PANI $/ \mathrm{TiO}_{2}=40 / 100$ before and after pyrolysis. The sample before pyrolysis exhibited strong absorption peaks at $1599,1464,1220$, and $1165 \mathrm{~cm}^{-1}$, which were assigned to the vibration of quinonediimine groups in PANI. The absorption peak at $1337 \mathrm{~cm}^{-1}$ was indexed to the stretching vibration absorption of the $\mathrm{N}-\mathrm{C}$ bond in phenylene diamine. Thus, the presence of PANI in the samples before calcination is confirmed. The absorption peaks of PANI disappeared following calcination. Two broad absorption bands at 1336 and 1558 $\mathrm{cm}^{-1}$, corresponding to the D and G bands of graphite carbon, respectively, were observed instead. Ring deformation vibration absorption peaks of PANI were observed at 414 and 522 $\mathrm{cm}^{-1}$ before pyrolysis and disappeared after pyrolysis.

Therefore, we can deduce that the structure of PANI was damaged during pyrolysis, resulting in the formation of graphitic carbon. The conductivity of this carbon material was better than that of the PANI fibers. Accordingly, the conductivity of the composite improved following pyrolysis, inhibiting the localized accumulation of products generated from oxygen reduction and thereby improving the activity of the composite towards oxygen reduction.

\section{Conclusions}

We prepared $\mathrm{TiO}_{2} / \mathrm{C}$ cathode catalysts and examined the in- 

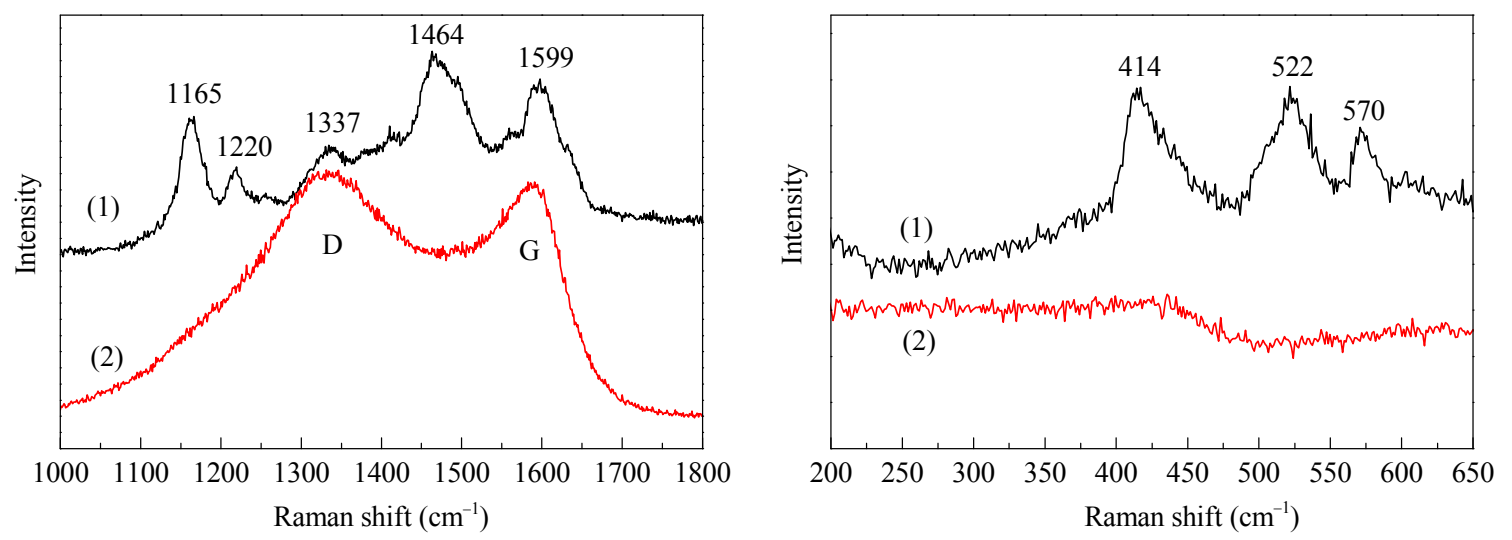

Fig. 11. Raman spectra of $\mathrm{TiO}_{2} / \mathrm{PANI}$ composite with $\mathrm{PANI} / \mathrm{TiO}_{2}=40 / 100$ before (1) and after (2) pyrolyzation at $800{ }^{\circ} \mathrm{C}$ for $1 \mathrm{~h}$ in $\mathrm{N}_{2}$.

fluence of the PANI-to- $\mathrm{TiO}_{2}$ mass ratios on the properties of the resulting composite materials. The influence of high-temperature treatment on the properties of the composite materials was also investigated. The results show the presence of bonding between the amidogen (or imido) of PANI and the hydroxy groups on the surface of $\mathrm{TiO}_{2}$ in the composite materials. The presence of this interaction prohibits the anatase-to-rutile $\mathrm{TiO}_{2}$ transformation and promotes adhesion of the $\mathrm{TiO}_{2}$ particles to the surface of PANI fibers, thereby inhibiting aggregation of $\mathrm{TiO}_{2}$. The catalyst prepared at $\mathrm{PANI} / \mathrm{TiO}_{2}=35 / 100$ and pyrolyzed displayed the best activity. The carbon material generated from the carbonization of PANI after the high-temperature treatment was found to coat the surface of the $\mathrm{TiO}_{2}$. The $\mathrm{TiO}_{2} / \mathrm{PANI}$ composite was transformed into $\mathrm{TiO}_{2} / \mathrm{C}$, leading to increased oxygen reduction activity. Concurrently, the hightemperature treatment caused $\mathrm{N}$ from the PANI framework to dope into the lattice of the graphitized carbon, further contributing to the increased oxygen reduction activity of the composite catalyst.

\section{References}

[1] Chisaka M, Ishihara A, Suito K, Ota K, Muramoto K. Electrochim Acta, 2013, 88: 697

[2] Ohgi Y, Ishihara A, Matsuzawa K, Mitsushima S, Ota K, Matsumoto M, Imai H.J Electrochem Soc, 2013, 160: F162

[3] Sarada B Y, Dhathathreyan K S, Krishna M R. Int J Hydrogen Energy, 2011, 36: 11886

[4] Ohgi Y, Ishihara A, Matsuzawa K, Mitsushima S, Ota K. J Electrochem Soc, 2010, 157: B885

[5] Takasu Y, Suzuki M, Yang H S, Ohashi T, Sugimoto W. Electrochim Acta, 2010, 55: 8220

[6] Ota K, Ohgi Y, Nam K D, Matsuzawa K, Mitsushima S, Ishihara A. J Power Sources, 2011, 196: 5256

[7] Seo J, Zhao L, Cha D, Takanabe K, Katayama M, Kubota J, Domen K. J Phys Chem C, 2013, 117: 11635

[8] Awaludin Z, Suzuki M, Masud J, Okajima T, Ohsaka T. J Phys Chem C, 2011, 115: 25557

[9] Ishihara A, Tamura M, Matsuzawa K, Mitsushima S, Ota K. Electrochim Acta, 2010, 55: 7581

\section{Graphical Abstract}

Chin. J. Catal., 2015, 36: 414-424 doi: 10.1016/S1872-2067(14)60223-0

\section{Pyrolyzed titanium dioxide/polyaniline as an efficient non-noble metal electrocatalyst for oxygen reduction reaction}

Zhijuan Zou, Hao Cheng, Jingyu Wang*, Xijiang Han

Harbin Institute of Technology; Huazhong University of Science and Technology
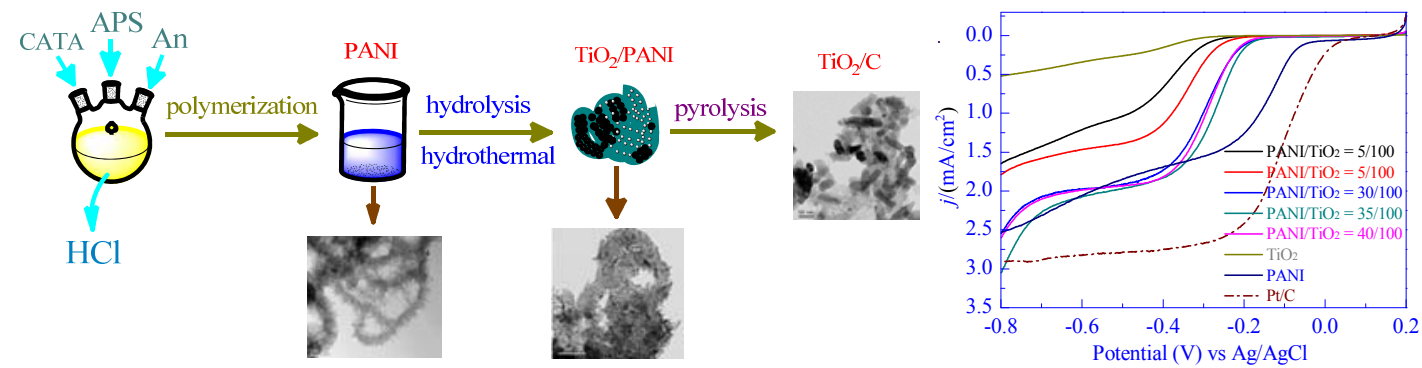

To overcome the prohibitive cost and poor durability of conventional Pt-based catalysts, $\mathrm{TiO}_{2} / \mathrm{C}$ was prepared by pyrolyzing a novel $\mathrm{TiO}_{2}$ /PANI composite. This non-noble metal electrocatalyst exhibits good ORR catalytic activity owing to the beneficial interaction between PANI and $\mathrm{TiO}_{2}$. 
[10] Ohgi Y, Ishihara A, Matsuzawa K, Mitsushima S, Ota K, Matsumoto M, Imai H. Electrochim Acta, 2012, 68: 192

[11] Chisaka M, Ijijima T, Yaguchi T, Sakurai Y. Electrochim Acta, 2011, 56: 4581

[12] Chisaka M, Suzuki Y, Iijima T, Sakurai Y. J Phy Chem C, 2011, 115: 20610

[13] Chisaka M, Suzuki Y, Iijima T, Ishihara Y, Inada R, Sakurai Y. ECS Electrochem Lett, 2012, 1: F4

[14] Jing M J, Wang Y, Qian J J, Zhang M, Yang J J. Chin J Catal (景明俊, 王岩, 钱俊杰, 张敏, 杨建军. 催化学报), 2012, 33: 550

[15] Jiang H Q, Wang Q F, Li S Y, Li J S, Wang Q Y. Chin J Catal (姜洪泉, 王巧风, 李世洋, 李井申, 王庆元. 催化学报), 2014, 35: 1068

[16] Li X G, Liu C P, Xing W, Lu T H. J Power Sources, 2009, 193: 470

[17] Selvarani G, Maheswari S, Sridhar P, Pitchumani S, Shukla A K. J Electrochem Soc, 2009, 156: B1354

[18] Jasin D, Abu-Rabi A, Mentus S, Jovanovic D. Electrochim Acta, 2007, 52: 4581

[19] Ioroi T, Akita T, Yamazaki S, Siroma Z, Fujiwara N, Yasuda K. J
Electrochem Soc, 2011, 158: C329

[20] Zhang H, Zhang J M, Xiao Q F. Chin J Power Sources (张浩, 张建民, 肖庆峰. 电源技术), 2007, 31: 551

[21] Dam D T, Nam K D, Song H, Wang X, Lee J M. Int J Hydrogen Energy, 2012, 37: 15135

[22] Zheng Y, Jiao Y, Chen J, Liu J, Liang J, Du A J, Zhang W M, Zhu Z H, Smith S C, Jaroniec M, Lu G Q, Qiao S Z. J Am Chem Soc, 2011, 133: 20116

[23] Yi B L. Fuel Cells: Mechanism, Technology, Application. Beijing: Chem Ind Press (衣宝廉. 燃料电池一一原理.技术.应用. 北京: 化 学工业出版社), 2004

[24] Gu L A, Wang J Y, Qi R, Wang X Y, Xu P, Han X J. J Mol Catal A, 2012, 357: 19

[25] Wu G, More K L, Johnston C M, Zelenay P. Science, 2011, 332: 443

[26] Lin Z Y, Waller G H, Liu Y, Liu M L, Wong C P. Carbon, 2013, 53: 130

[27] Zhang N, Zhang S, Zhu T, Yin G P. Progr Chem (张娜, 张生, 朱娅, 尹鸽平. 化学进展), 2011, 23: 2240

\title{
热解二氧化钛/聚苯胺制备高效非贵金属氧还原电催化剂
}

\author{
邹志娟 ${ }^{\mathrm{a}}$, 程 皓 ${ }^{\mathrm{a}}$, 王靖宇 ${ }^{\mathrm{a}, \mathrm{b},}{ }^{*}$, 韩喜江 ${ }^{\mathrm{a}, \#}$ \\ a哈尔滨工业大学化学系, 黑龙江哈尔滨 150001 \\ ${ }^{\mathrm{b}}$ 华中科技大学化学与化工学院, 大型电池关键材料与系统教育部重点实验室, 湖北武汉 430074
}

摘要: 为了克服传统 $\mathrm{Pt}$ 系催化剂价格昂贵、稳定性差的缺点, 采用热解新型 $\mathrm{TiO}_{2} /$ 聚苯胺 $(\mathrm{PANI})$ 复合物的方法合成了 $\mathrm{TiO}_{2} / \mathrm{C}$ 催化剂. 用扫描电子显微镜、X射线光电子能谱、X射线衍射、傅里叶变换红外光谱、拉曼光谱、透射电子显微镜、循环伏安法和线性扫 描伏安法等方法研究了热处理和PANI复合比例对复合物的形貌、成键、晶相组成及氧还原性能的影响. 结果表明, $\mathrm{PANI} \mathrm{TiO}_{2}$ 间存在相互作用, 可以抑制 $\mathrm{TiO}_{2}$ 的团聚和锐钛矿向金红石的转变. 热处理制得 $\mathrm{TiO}_{2} / \mathrm{C}$ 的氧还原活性随着PANI载体含量增加先升 高后降低, $\mathrm{PANI}$ 和 $\mathrm{TiO}_{2}$ 质量比为 $35 / 100$ 时, 催化剂的氧还原活性最高. 同时, 循环伏安和时间-电流曲线测试表明, 已制备的复合 材料在催化氧还原反应进行时具有较好的稳定性.

关键词：聚苯胺; 二氧化钛; 热解; 阴极催化剂; 氧还原

收稿日期: 2014-07-13. 接受日期: 2014-09-04. 出版日期: 2015-03-20.

*通讯联系人. 电话: (0451)86413702; 传真: (0451)86418750; 电子信箱: jingyu.wang@163.com

\#通讯联系人. 电话: (0451)86413702; 传真: (0451)86418750; 电子信箱: hanxijiang@hit.edu.cn

基金来源：国家自然科学基金(21001037, 21071037, 91122002); 哈尔滨技术创新人才专项基金(2013RFLXJ011); 华中科技大学引 进人才科研基金(2014036).

本文的英文电子版由Elsevier出版社在ScienceDirect上出版(http://www.sciencedirect.com/science/journal/18722067).

\section{1. 前言}

目前,制备廉价、高效、稳定的催化剂是燃料电池 阴极材料研究的热点. 第 IV、V 副族金属氧化物因其在 酸中不可溶, 被认为是具有前景的燃料电池阴极催化剂 备选材料 ${ }^{[1]}$. 以锆 ${ }^{[2-6]}$ 、锄 ${ }^{[5-10]}$ 、铌 ${ }^{[6]}$ 、铁 ${ }^{[5,11]}$ 和铪 ${ }^{[11-13]}$ 的 氧化物作为阴极氧还原催化剂的研究已见报道, 合成方 法也多种多样. $\mathrm{TiO}_{2}$ 是一种前景广阔、研究广泛的光催 化剂, 有关其合成、形貌及晶相控制、改性及与其他材 料复合方面的研究已十分深入 ${ }^{[14,15]}$. 近来, $\mathrm{TiO}_{2}$ 也被用作 燃料电池阴极催化剂. 由于 $\mathrm{TiO}_{2}$ 具有良好的稳定性, 常被 作为催化剂基底材料. $\mathrm{TiO}_{2}$ 能够提高阴极催化剂的稳定
性 ${ }^{[16]}$ 、抗甲醇性能、4电子反应的选择性和催化活性 ${ }^{[17,18]}$. 此外, 非化学计量比 $\mathrm{TiO}_{2}$ 也被用作基底材料 ${ }^{[19]}$.

值得注意的是, $\mathrm{TiO}_{2}$ 本身也是一种氧还原催化剂. Zhang等 ${ }^{[20]}$ 通过 $\mathrm{TiCl}_{4}$ 水解后高温热处理的方法制备阴极 催化剂, 并将其用于锌-空气电池. Dam等 ${ }^{[21]}$ 用 $\mathrm{TiO}_{2}$ 制备 的钛的碳氮化物, 再经过高温煅烧, 得到的 TiCNO是一种 由 $\mathrm{TiO}_{2}$ 和 $\mathrm{TiCN}$ 混合而成的催化剂, 与纯 $\mathrm{TiO}_{2}$ 相比, 其氧 还原初始电位和极限电流都有明显变化. Chisaka等 ${ }^{[1]}$ 也 采用热处理 $\mathrm{TiCN}$ 的方法制备了以金红石相 $\mathrm{TiO}_{2}$ 为主体 的阴极催化剂. 他们发现材料中残留的 $\mathrm{C}$ 并没有掺杂到 $\mathrm{TiO}_{2}$ 中形成杂质缺陷, $\mathrm{C}$ 在高温热处理过程中结合成石 墨烯后包覆在 $\mathrm{TiO}_{2}$ 表面, 在氧还原过程中起到了传递电 
子的作用. 部分 $\mathrm{N}$ 与 $\mathrm{Ti}$ 形成 $\mathrm{TiN}$, 这部分 $\mathrm{N}$ 原子由于没有 掺杂到 $\mathrm{TiO}_{2}$, 故对氧还原活性没有影响, 但高温热处理过 程中在 $\mathrm{TiO}_{2}$ 中产生的氧缺陷和掺杂 $\mathrm{N}$ 对 $\mathrm{TiO}_{2}$ 氧还原活性 的提高具有很大作用. 近年研究表明, $\mathrm{TiO}_{2}(110)$ 晶面由 于更容易吸附氧气, 对氧还原反应有利 ${ }^{[11]}$. 尽管已经取 得一定的研究成果, 但是无论是 $\mathrm{TiO}_{2}$ 氧还原机理, 还是 $\mathrm{TiO}_{2}$ 作为催化剂或催化剂载体的性能仍需进行深入探 讨. 目前在 $\mathrm{TiO}_{2}$ 合成、改性及与其他材料复合等方面已 取得的研究成果具有借鉴意义.

二氧化钛是一种半导体, 电导率低限制了其在氧还 原反应中的应用. Zheng等 ${ }^{[22]}$ 通过第一性原理计算发现, 对于电导率低的材料, 电子转移效率低, 反应被限制在物 质界面处的小区域内, 氧还原反应倾向于发生 2 电子过 程, 生成物为 $\mathrm{H}_{2} \mathrm{O}_{2}$ 和 $\mathrm{HO}_{2}{ }^{-}$离子, 生成物会不断积累, 不利 于反应的继续进行; 导电碳材料的引入, 有利于氧气通 过4电子过程还原, 提高了材料的氧还原性能. 以上结论 在实验上也得到了证实 ${ }^{[22]}$. Chisaka 等 ${ }^{[1]}$ 通过在 $\mathrm{N}_{2}-\mathrm{H}_{2}$ 混 合气的气氛中高温热处理钛的碳氮化物制备了具有氧 还原活性的 $\mathrm{TiO}_{2}$, 研究发现 $\mathrm{C}$ 并没有掺入 $\mathrm{TiO}_{2}$ 晶格中, 而 是以单层石墨的形式存在于 $\mathrm{TiO}_{2}$ 表面, $\mathrm{C}$ 在其中的主要 作用为传输电子 ${ }^{[23]}$, 结果高温热处理过程中形成的氧缺 陷在提高氧还原催化剂性能方面有决定性作用.

本文使用水热法合成了新型 $\mathrm{TiO}_{2} / \mathrm{PANI}$ 复合物, 再 经过高温热解, 制备了 $\mathrm{TiO}_{2} / \mathrm{C}$ 催化剂. 采用X射线衍射 (XRD) 和扫描电子显微镜 $(\mathrm{SEM})$ 等技术研究了 $\mathrm{TiO}_{2} / \mathrm{C}$ 的 形貌和晶相组成, 并对催化剂进行了电化学测试. 着重 研究了聚苯胺 $(\mathrm{PANI})$ 和 $\mathrm{TiO}_{2}$ 的比例和热解温度对催化 剂氧还原性能的影响, 寻找最佳实验条件, 为 $\mathrm{TiO}_{2}$ 在氧还 原催化剂方面的研究提供一定的借鉴.

\section{2. 实验部分}

\section{1. 催化剂的制备}

将 $2.282 \mathrm{~g}$ 过硫酸铵(APS, A.R., 天津大茂化学试剂 厂)用 $\mathrm{HCl}(36 \%, \mathrm{~A} . \mathrm{R}$. , 北京化工厂)溶液 $(0.1 \mathrm{~mol} / \mathrm{L})$ 溶解后 预冷却备用. 称取 $0.3411 \mathrm{~g}$ 十六烷基三甲基氯化铵 (CTAC, A.R., 天津光复精细化工厂), 用 $\mathrm{HCl}$ 溶液 (0.1 $\mathrm{mol} / \mathrm{L}$ ) 溶解后加入到三口烧瓶中, 再加入 $0.92 \mathrm{~mL}$ 苯胺 (A.R., 国药集团化学试剂有限公司), 体系在冰水浴条件 下机械摚拌 $1 \mathrm{~h}$, 使苯胺单体分散均匀. 加入预先冷却的 APS 溶液, 使苯胺单体发生聚合反应, 体系仍保持冰水 浴, 继续机械搅拌 $24 \mathrm{~h}$. 反应过程中, 使用的 $\mathrm{HCl}$ 溶液 $(0.1$ $\mathrm{mol} / \mathrm{L}$ )总体积为 $100 \mathrm{~mL}$. 反应结束后, 将产物离心, 用工
业乙醇、蒸馏水和无水乙醇(A.R., 国药集团化学试剂有 限公司)各离心洗涤三次, 最后用无水乙醇分散并定容至 $80 \mathrm{~mL}$ 备用. 准确量取 $20 \mathrm{~mL}$ PANI乙醇分散液, 离心后置 于真空干燥箱中 $60{ }^{\circ} \mathrm{C}$ 干燥 $6 \mathrm{~h}$, 由固体粉末质量计算 PANI纳米纤维分散液质量浓度为 $11.46 \mathrm{mg} / \mathrm{mL}$, PANI收 率约为 $97.6 \%$.

取 $3 \mathrm{~mL}$ 钛酸正四丁酯(A.R., 国药集团化学试剂有限 公司)和适量无水乙醇混合, 超声分散均匀后, 向混合物 中加入适量的PANI无水乙醇分散液, 继续超声分散 10 $\min$, 反应中加入无水乙醇和PANI无水乙醇分散液的总 体积为 $30 \mathrm{~mL}$. 磁力摚拌下, 向混合均匀的溶液中滴加 10 $\mathrm{mL}$ 蒸馏水, 将反应体系置于 $70{ }^{\circ} \mathrm{C}$ 水浴中继续摚拌 30 $\mathrm{min}$, 使钛酸正四丁酯充分水解. 得到的沉淀物经过离心, 用蒸馏水洗涤三次. 用 $60 \mathrm{~mL} \mathrm{HCl}$ 溶液 $(1 \mathrm{~mol} / \mathrm{L})$ 溶解沉淀 物, 转移到 $250 \mathrm{~mL}$ 三口烧瓶中, $70^{\circ} \mathrm{C}$ 水浴条件下机械摚 拌 $4 \mathrm{~h}$. 将溶液转移到 $35 \mathrm{~mL}$ 的水热釜中, $150^{\circ} \mathrm{C} 反$ 应 $18 \mathrm{~h}$. 然后离心, 用工业乙醇洗三次, 蒸馏水洗三次, $60^{\circ} \mathrm{C}$ 烘干. 将得到的固体研磨, 之后在 $\mathrm{N}_{2}$ 保护下用管式炉 $800^{\circ} \mathrm{C}$ 高 温处理即得到 $\mathrm{TiO}_{2} / \mathrm{C}$.

\section{2. 催化剂的表征}

样品的XRD谱测试在日本Rigaku D/Max-RB型X射 线衍射仪上进行, $\mathrm{Cu}$ 靶, $K_{\alpha}$ 辐射, 管电压为 $40 \mathrm{kV}$, 工作电 流 $30 \mathrm{~mA}$. 利用飞利浦公司FEI-Sirion 200 场发射SEM和 FEITECNAIG2透射电子显微镜(TEM)分析材料的形貌. 采用Renishaw inVia拉曼光谱仪采集样品的拉曼响应信 号, 激光器为氦氮激光器, 波长为 $633 \mathrm{~nm}$, 功率为 $0.1 \mathrm{~mW}$. 使用美国Nicolet公司Avatar 360傅里叶变换红外光谱仪 (FT-IR) 测试样品的红外吸收峰. 利用ULVAC 公司 PHI5700ESCA型X射线光电子能谱(XPS)分析样品的元 素和成键状况. 样品的热分析在美国TA公司SDT Q600 型热重-差示扫描热分析以上进行.

\section{3. 催化剂的性能}

称取 $4 \mathrm{mg}$ 催化剂置于 $1.5 \mathrm{~mL}$ 离心管, 依次加入 $0.4 \mathrm{~mL}$ 无水乙醇、 $0.4 \mathrm{~mL}$ 蒸馏水和 $20 \mu \mathrm{L}$ 质量分数为 $0.5 \%$ 的 Nafion溶液(由 $5 \%$ Nafion溶液分散于异丙醇(分析纯, 阿 法埃莎天津化学有限公司)制得), 超声分散均匀后得催 化剂分散液. 用移液器量取 $4 \mu \mathrm{L}$ 催化剂分散液滴于玻碳 RDE表面(电极直径为 $4 \mathrm{~mm}$ ), 使催化剂在玻碳电极表面 均匀铺展, 自然晾干即得所需工作电极. 测试后, 电极依 次用蒸馏水和无水乙醇清洗干净, 晾干方可进行下一次 测试.

实验使用上海辰华CHI650D电化学工作站采集数 
据. 测试在三电极体系中进行: 工作电极为滴有催化剂 分散液的玻碳旋转圆盘电极; 对电极是铂丝; 参比电极 是 $\mathrm{Ag} / \mathrm{AgCl}$ 电极; $\mathrm{KOH}$ (A.R., 天津市风船化学试剂科技 有限公司) 溶液 $(0.1 \mathrm{~mol} / \mathrm{L})$ 作为电解质溶液. 为保证气体 饱和, 每次测试前需要通入气体 $30 \mathrm{~min}$ 左右. 扫描范围是 0.2 到 $-0.8 \mathrm{~V}$, 扫描速度是 $5 \mathrm{mV} / \mathrm{s}$.

\section{3. 结果与讨论}

\subsection{PANI与 $\mathrm{TiO}_{2}$ 复合比例对 $\mathrm{TiO}_{2} / \mathrm{C}$ 催化性能的影响}

图1为PANI与 $\mathrm{TiO}_{2}$ 复合前后的 TEM照片. 从图1(b) 可以发现, 盐酸掺杂PANI呈现纤维状结构, 并且纤维表 面不光滑为毛刺状. 图1(a)中 $\mathrm{TiO}_{2}$ 紧密均匀包覆在PANI 纳米纤维表面.

用XRD研究了复合物中 $\mathrm{TiO}_{2}$ 的晶相组成及PANI对 $\mathrm{TiO}_{2}$ 的作用. 结果显示, PANI的存在使 $\mathrm{TiO}_{2}$ 的晶相组成 和晶体尺寸发生了变化. 图 2 为不同 $\mathrm{PANI} / \mathrm{TiO}_{2}$ 质量比 (其中 $\mathrm{TiO}_{2}$ 的质量按照理论产量计算) 时 $\mathrm{TiO}_{2} / \mathrm{PANI}$ 复合 物的XRD谱. 可以看出, 随着PANI含量的增加, 复合物中 锐钛矿 $\mathrm{TiO}_{2}$ 的含量逐渐增加, 金红石相 $\mathrm{TiO}_{2}$ 的含量逐渐 减少, 但金红石始终是复合物中 $\mathrm{TiO}_{2}$ 的主要晶相. 当 $\mathrm{PANI} / \mathrm{TiO}_{2}=1 / 100$ 时, 复合材料中的 $\mathrm{TiO}_{2}$ 全部以金红石 相存在; 当 $\mathrm{PANI} / \mathrm{TiO}_{2}=40 / 100$ 时, 金红石所占的比例降 低为 $74.6 \%$, 而锐钛矿的比例增加到 $25.4 \%$. 这是因为从 热力学角度分析, 金红石相是 $\mathrm{TiO}_{2}$ 最为稳定的晶相, 在水 热和高浓度盐酸的条件下, $\mathrm{TiO}_{2}$ 应该全部转化为金红石 相. 然而, 在 $\mathrm{TiO}_{2}$ 结晶过程中引入一维PANI纳米纤维后, 生成的 $\mathrm{TiO}_{2}$ 会和PANI纤维表面形成相互作用, 这种相互 作用的存在抑制了 $\mathrm{TiO}_{2}$ 从锐钛矿相向金红石的转变, 使 得复合物中有锐钛矿相 $\mathrm{TiO}_{2}$ 存在 ${ }^{[24]}$. 此外, 也有研究表 明, 锐钛矿向金红石的转变发生在锐钛矿颗粒间接触的 地方, 抑制锐钣矿纳米颗粒的团聚将有利于抑制其向金 红石转变. 从图2中还可发现, XRD衍射峰的强度随着 PANI含量的增加而减弱, 并且峰出现宽化现象, 可以推 测随着PANI含量增加, 复合物中 $\mathrm{TiO}_{2}$ 附着在PANI纤维 表面, 减少了 $\mathrm{TiO}_{2}$ 团聚, 也抑制了 $\mathrm{TiO}_{2}$ 颗粒尺寸增长, 使 得 $\mathrm{TiO}_{2}$ 晶粒尺寸减小. 为证明这一点, 根据谢乐公式计算 出复合物中 $\mathrm{TiO}_{2}$ 的晶粒尺寸, 结果见表 1 .

PANI与 $\mathrm{TiO}_{2}$ 间相互作用的存在从FT-IR谱中也可得 到证明. 图3 为 $\mathrm{PANI}$ 和 $\mathrm{TiO}_{2}$ 质量比不同时 $\mathrm{TiO}_{2} / \mathrm{PANI}$ 的 红外吸收光谱. PANI的主要特征峰如下: 位于 $3502 \mathrm{~cm}^{-1}$ 处为 $\mathrm{N}-\mathrm{H}$ 单键的伸缩振动吸收峰; $1573 \mathrm{~cm}^{-1}$ 处为 $\mathrm{C}=\mathrm{N}$ 的 伸缩振动吸收峰; $1490 \mathrm{~cm}^{-1}$ 处为 $\mathrm{C}=\mathrm{C}$ 双键的伸缩振动;
1305 和 $1248 \mathrm{~cm}^{-1}$ 处是苯环中 $\mathrm{C}-\mathrm{N}$ 单键的伸缩振动吸收 峰; 1143 和 $802 \mathrm{~cm}^{-1}$ 处吸收峰则分别归属于掺杂聚苯胺 中的醌环和苯环. 在复合物的红外吸收光谱中, 400-1000 $\mathrm{cm}^{-1}$ 范围内的红外吸收是由 $\mathrm{TiO}_{2}$ 组分中的 O-Ti-O网状结构引起的, 而PANI组分位于 $802 \mathrm{~cm}^{-1}$ 及更 低波数处的小吸收峰仍能分辨. 当复合物中 $\mathrm{TiO}_{2}$ 含量较 高时, 虽然复合物的主要成分是 $\mathrm{TiO}_{2}$, 但由于相互作用的 存在, 导致这一吸收峰和PANI低波数的吸收峰重合, 802 $\mathrm{cm}^{-1}$ 吸收峰逐渐消失, O-Ti-O吸收峰的位置发生偏移, 并且聚苯胺的其余吸收峰减弱, 由此可以证明, PANI和 $\mathrm{TiO}_{2}$ 间存在相互作用. 我们推测是PANI中的 $\mathrm{N}-\mathrm{H}$ 与 $\mathrm{TiO}_{2}$ 表面的羟基在二者界面间发生了相互作用 ${ }^{[22]}$.

为进一步印证 $\mathrm{TiO}_{2}$ 与 PANI间存在相互作用, 对 $\mathrm{PANI} / \mathrm{TiO}_{2}=40 / 100$ 的 $\mathrm{TiO}_{2} / \mathrm{PANI}$ 复合物进行了 XPS测试, 分析复合物中各元素的结合能和元素之间的成键状况. 图 4(a)为 $\mathrm{PANI} / \mathrm{TiO}_{2}=40 / 100$ 时 $\mathrm{TiO}_{2} / \mathrm{PANI}$ 复合物的XPS 全谱. 从图可知, 复合物中含有 $\mathrm{C}, \mathrm{O}, \mathrm{Ti}$ 和 $\mathrm{N}$ 四种元素, 其 中光谱信号分别对应于 $\mathrm{C} 1 s, \mathrm{O} 1 s, \mathrm{Ti} 2 p$ 和 $\mathrm{N} 1 s$, 结合能分 别为 $284.3,530.1,458.8$ 和 $400.1 \mathrm{eV}$. 经计算可知, 这四种 元素所占比例由大到小依次为 C $49.95 \%, \mathrm{O} 33.35 \%$, Ti $13.20 \%, \mathrm{~N} 3.5 \%$. 图4(b)和(c)分别为 C $1 s$ 和 $\mathrm{O} 1 s$ 的高分辨 XPS 谱. 经过高斯拟合, $\mathrm{C} 1 s$ 谱可以细分为 $284.6,286.4$ 和 $288.5 \mathrm{eV}$ 处的三个峰. 其中结合能为 $288.5 \mathrm{eV}$ 的碳原子说 明体系中 $\mathrm{C}-\mathrm{O}-\mathrm{Ti}$ 化学键的存在. O $1 s$ 峰去卷积计算后可 以分为两个峰, 分别位于 530.0 和 $531.9 \mathrm{eV}$, 其中 $530.0 \mathrm{eV}$ 对应于 $\mathrm{Ti}-\mathrm{O}$ 键中 $\mathrm{O} 1 \mathrm{~s}$ 轨道的结合能, 而 $531.9 \mathrm{eV}$ 处的 $\mathrm{O} 1 \mathrm{~s}$ 峰则说明了 $\mathrm{TiO}_{2}$ 中 $\mathrm{Ti}-\mathrm{O}$ 键环境发生变化. 结合 XRD 与 FT-IR的分析结果, 我们认为, 在复合材料制备过程中, PANI通过氨基(或亚氨基)与 $\mathrm{TiO}_{2}$ 表面的羟基形成了类 似氢键的化学键 ${ }^{[22]}$.

在此基础上,用线性扫描伏安法测试了 $\mathrm{TiO}_{2} / \mathrm{PANI}$ 热解前后 $\mathrm{TiO}_{2} / \mathrm{C}$ 催化氧还原反应的能力. 图 5 为 $\mathrm{PANI}$ 与 $\mathrm{TiO}_{2}$ 质量比不同时 $\mathrm{TiO}_{2} / \mathrm{PANI}$ 复合物热解前后的LSV曲 线. 随着PANI含量增加, $\mathrm{TiO}_{2} / \mathrm{C}$ 催化氧还原反应能力增 大. 当 $\mathrm{PANI} / \mathrm{TiO}_{2}=100 / 30-100 / 40$ 时, 得到的 $\mathrm{TiO}_{2} / \mathrm{C}$ 氧还 原活性最高. 这是由于 $\mathrm{TiO}_{2}$ 的导电性差, 引入导电性较好 的物质可以提高 $\mathrm{TiO}_{2}$ 的氧还原活性. 同时, 聚苯胺骨架中 的氮元素也是氧还原反应的活性中心 ${ }^{[25,26]}$, 随着复合物 中PANI含量增加, 热解后得到的 C-N含量增加, 因而电 催化氧还原反应速率加快 ${ }^{[25,26]}$. 我们发现, 复合材料中 PANI含量的进一步增加并不能带来催化活性的持续增 加, 说明PANI与 $\mathrm{TiO}_{2}$ 二者界面间的相互作用受到限制, 
不能很好发挥 $\mathrm{TiO}_{2}$ 作为助催化剂的作用. 通过与纯PANI 热解后的样品进行对比, 我们推测复合材料中氧还原活 性提高的瓶颈主要源于纯PANI热解后氮掺杂碳材料本 身的催化活性, 这些样品的催化活性均与商业 $\mathrm{Pt} / \mathrm{C}$ 存在 一定差距. $\mathrm{Pt} / \mathrm{C}$ 的 LSV曲线有一个很宽的电流稳定平台, 且有很强的极限电流密度, 其催化机理为 $4 \mathrm{e}^{-}$主导的扩散 电流控制的ORR机理. 纯PANI热解后制得的氮掺杂碳 材料在LSV曲线中几乎观察不到电流稳定平台, 暗示这 可能是 $2 \mathrm{e}^{-}$转移过程, 也就是说, $\mathrm{O}_{2}$ 只能转化为 $\mathrm{OOH}^{-[22]}$, 其性能与文献报道的氧化石墨烯(GO)-PANI热解后得到 的氮掺杂石墨烯材料相距甚远 ${ }^{[26]}$. $\mathrm{TiO}_{2} / \mathrm{PANI}$ 热解形成 的 $\mathrm{TiO}_{2} / \mathrm{C}$ 复合催化剂在 $\mathrm{LSV}$ 曲线中有一段明显的电流稳 定平台, 此后电流密度持续增加, 故推测是 $2 \mathrm{e}^{-}$和 $4 \mathrm{e}^{-}$共同 作用的结果.

虽然金属氧化物对碳材料催化活性的增强作用并 非令人满意, 但是近几年有关金属氧化物用于燃料电池 的研究逐渐增多. 原因在于, 金属氧化物不仅可以降低 燃料电池的成本, 更为重要的是, 可以显著提高催化剂的 电化学稳定性, 延长燃料电池的使用寿命 ${ }^{[27]}$. 因此, 我们 测试了 $\mathrm{PANI} / \mathrm{TiO}_{2}=40 / 100$ 时的复合物以及纯PANI碳化 后样品的电流-时间曲线, 如图6所示. 从图中可以看出, 在相同条件下经过 $5000 \mathrm{~s}$ 反应之后, 复合材料的电流损 失仅为 $13 \%$, 而对于PANI碳化所得的氮掺杂碳材料, 该 损失高达 $32 \%$. 也就是说, 直接热解PANI制备的氮掺杂 碳材料虽然在活性上略优于 $\mathrm{PANI} / \mathrm{TiO}_{2}=40 / 100$ 的碳化 产物, 但前者在反应过程中的稳定性却比复合物低很多. 另外, 对复合材料进行了循环伏安 $(\mathrm{CV})$ 测试以研究所得 $\mathrm{TiO}_{2} / \mathrm{C}$ 的循环稳定性, 如图7所示. 从图上可直观地看出, 在 100 次循环后, $\mathrm{TiO}_{2} / \mathrm{C}$ 复合材料的电化学响应并没有明 显变化, 这与上述电流-时间曲线的结果一致. 因此, 将 $\mathrm{TiO}_{2}$ 引入导电聚合物再一起碳化, 一方面可以降低催化 剂中的碳含量, 另一方面有利于碳材料作为电催化剂或 载体的循环稳定性.

此外, 对未碳化的PANI/ $\mathrm{TiO}_{2}=40 / 100$ 复合物进行了 热重分析, 确定其中 PANI和 $\mathrm{TiO}_{2}$ 的真实含量. 图 8 为 $\mathrm{PANI} / \mathrm{TiO}_{2}=40 / 100$ 时复合物在空气中的热稳定性. 复合 材料加热到 $950{ }^{\circ} \mathrm{C}$ 后, 总失重是 $34.8 \%$, 其中在 $0-100{ }^{\circ} \mathrm{C}$ 范 围内失重 $4.0 \%$, 这一失重是由吸附水蒸发引起的, 其余 $30.8 \%$ 的失重是由于复合材料中的PANI在空气中燃烧.

\section{2. 热解对 $\mathrm{TiO}_{2} / \mathrm{C}$ 材料氧还原性能的影响}

图 9 为 $\mathrm{PANI} / \mathrm{TiO}_{2}=40 / 100$ 时的复合物在氮气中
$800{ }^{\circ} \mathrm{C}$ 热解 $1 \mathrm{~h}$ 后得到的 $\mathrm{TiO}_{2} / \mathrm{C}$ 的 TEM照片. 对比图 1(a) 和图3, 可以发现纤维状结构消失, $\mathrm{TiO}_{2}$ 被没有固定形貌 的碳材料包覆. 热解的作用是使PANI碳化成为碳材料.

图 10 为 $\mathrm{PANI} / \mathrm{TiO}_{2}=40 / 100$ 时复合物热处理前后的 FT-IR谱. 热处理后PANI在 $3416 \mathrm{~cm}^{-1}$ 处 $\mathrm{N}-\mathrm{H}$ 单键的伸缩 振动, 在 1575 和 $1487 \mathrm{~cm}^{-1}$ 处醌环和苯环中 $\mathrm{C}=\mathrm{N}$ 和 $\mathrm{C}=\mathrm{C}$ 双 键的伸缩振动, 在 1301 和 $1243 \mathrm{~cm}^{-1}$ 处 $\mathrm{C}-\mathrm{N}$ 单键的伸缩振 动, 在 $1145 \mathrm{~cm}^{-1}$ 处掺杂PANI中的醌环吸收峰和 $793 \mathrm{~cm}^{-1}$ 以下的吸收峰均消失. 热处理前后的样品在400-1000 $\mathrm{cm}^{-1}$ 范围内都有红外吸收, 证明碳化前后O-Ti-O网状结 构基本没有变化, 并且在 $1585 \mathrm{~cm}^{-1}$ 处出现一个小吸收峰, 这一吸收峰被认为是由 $\mathrm{TiO}_{2}$ 表面吸附水分产生的. 可见, 高温处理的过程中, 破坏了 PANI的原有结构, 而 $\mathrm{TiO}_{2}$ 中 $\mathrm{O}-\mathrm{Ti}-\mathrm{O}$ 网状结构没有发生较大变化.

图 11 为 $\mathrm{TiO}_{2} / \mathrm{PANI}=100 / 40$ 时复合物碳化前后的拉 曼光谱. 碳化前样品在 $1599,1464,1220$ 和 $1165 \mathrm{~cm}^{-1}$ 等处 有强吸收峰, 这些吸收峰显然来自PANI中醌二亚胺基团 的振动. $1337 \mathrm{~cm}^{-1}$ 处的峰为苯二胺中 $\mathrm{N}-\mathrm{C}$ 单键伸缩振动. 由此确定煅烧前样品中PANI的存在. 碳化后样品中 PANI的吸收峰消失, 取而代之的是以 1336 和 $1588 \mathrm{~cm}^{-1}$ 为 中心的两个宽吸收峰. 这两个吸收峰分别为石墨相碳材 料的D带和 G带. 此外, PANI在 414 和 $522 \mathrm{~cm}^{-1}$ 处有环变形 振动的吸收峰; 碳化后, 这一变形振动吸收峰也消失.

由此, 我们可以确定碳化后材料中的PANI结构被破 坏, 形成了石墨相结构的碳. 碳材料的导电性优于PANI 纤维. 因此, 碳化改善了材料的导电性, 避免了氧还原反 应产物在局部积累,提高了材料的氧还原活性.

\section{4. 结论}

合成了 $\mathrm{TiO}_{2} / \mathrm{C}$ 阴极催化剂, 研究了复合物中PANI和 $\mathrm{TiO}_{2}$ 比例和热处理对材料性能的影响. 结果表明, 在 $\mathrm{TiO}_{2} / \mathrm{PANI}$ 复合物中, $\mathrm{PANI}$ 中的氨基(或亚氨基)与 $\mathrm{TiO}_{2}$ 表面羟基间有键合作用. 由于这种相互作用的存在, 抑 制了 $\mathrm{TiO}_{2}$ 由锐钛矿向金红石的转变, 并且使 $\mathrm{TiO}_{2}$ 颗粒附 着在PANI纳米纤维表面, 减少了 $\mathrm{TiO}_{2}$ 的团聚. 当复合物 中PANI $/ \mathrm{TiO}_{2}=35 / 100$ 时, 热解后得到的催化剂活性最好. 高温热处理可以使PANI发生碳化生成的碳材料包覆在 $\mathrm{TiO}_{2}$ 表面, 材料由 $\mathrm{TiO}_{2} / \mathrm{PANI}$ 变为 $\mathrm{TiO}_{2} / \mathrm{C}$, 氧还原活性明 显提高. 同时在高温热处理过程中,PANI骨架中的氮元 素在碳化过程中掺杂入石墨化碳的晶格, 有利于氧还原 活性的提高. 